\title{
Potassium-bearing clinopyroxene: thermodynamic models and application to the barometry of mantle assemblages
}

\author{
Oleg G. Safonov ${ }^{1,3}$, Victor L. Vinograd ${ }^{2}$, Dan J. Wilson ${ }^{2}$, Leonid L. Perchuk ${ }^{3,1}$ and \\ Björn Winkler ${ }^{2}$ \\ ${ }^{1}$ Institute of Experimental Mineralogy,Chernogolovka, Russia; oleg@iem.ac.ru \\ ${ }^{2}$ University of Frankfurt, Institute of Geosciences, Frankfurt a.M., Germany \\ ${ }^{3}$ Department of Petrology, Faculty of Geology, Moscow State University, Moscow, Russia
}

Potassium-bearing clinopyroxenes (KCpx) have been described as inclusions in diamonds (Ricard et al., 1989; Harlow \& Veblen, 1991; Stachel et al., 2000), in mantle xenoliths (e.g. Jaques et al., 1990), and in Grt-Cpx rocks of the Kokchetav Complex (Sobolev \& Shatsky, 1990; Perchuk et al., 2002). Typically, the concentration of $\mathrm{K}_{2} \mathrm{O}$ in the clinopyroxenes does not exceed 1.7 wt. \%. However, the finding of the samples with 2.3 and 3.6 wt. $\%$ of $\mathrm{K}_{2} \mathrm{O}$ (Ghorbani \& Middlemost, 2000; Bindi et al., 2003) and the experimental studies of Harlow (1997, 1999), Chudinovskikh et al. (2001) and Safonov et al. (2003, 2004, 2005a) have shown that the structure of Cpx is able to accommodate much higher concentrations of potassium.

The available experimental and crystal chemical data (Harlow, 1996; Bindi et al., 2002, 2006) suggest that the $\mathrm{K}_{2} \mathrm{O}$ content of clinopyroxenes is sensitive to the pressure of their equilibration in rocks. Here we discuss three barometric approaches based on the KCpx equilibria: (1) the empirical correlation between the $\mathrm{K} / \mathrm{Na}$ ratio of clinopyroxenes and pressure (Safonov et al., 2004); (2) the empirically calibrated equilibrium $\mathrm{KJd}(\mathrm{Cpx})=\mathrm{KAlSi}_{2} \mathrm{O}_{6}$ (melt) (Safonov et al., 2005b); (3) the thermodynamic assessment of mineral equilibria based on theoretically calculated standard properties of $\mathrm{KJd}$ and thermodynamic mixing functions of the KJd-Di solid solution (Vinograd et al., in press).

\section{Na-avoidance in the cpx}

The negative correlation between $\mathrm{K}$ and $\mathrm{Na}$ contents is typical for clinopyroxenes from inclusions in diamonds (Sobolev et al., 1997a, 1998; Kaminsky et al., 2000; Pokhilenko et al., 2004). The experimental studies in the system $\mathrm{CaMgSi}_{2} \mathrm{O}_{6}-\mathrm{NaAlSi}_{2} \mathrm{O}_{6}$ $\mathrm{KAlSi}_{2} \mathrm{O}_{6}$ at 5-7 GPa (Safonov et al., 2004) and in the omphacite- $\mathrm{K}_{2} \mathrm{CO}_{3}$ system at $10 \mathrm{GPa}$ (Harlow, 1997) confirmed this observation and showed that the $\mathrm{K} / \mathrm{Na}$ ratio in the $\mathrm{Cpx}$ is sensitive to the formation pressure. Fig. 1 shows a correlation between $\mathrm{Na}-$ and $\mathrm{K}$ contents of omphacite inclusions in diamonds from which the formation pressures can be inferred. For example, the Cpx inclusions in diamonds from the Argyle lamproites (Jaques et al., 1989) and Guaniamo kimberlites (Sobolev et al., 1998; Kaminsky et al., 2000) correspond to pressures of $\sim 6.5$ and $\sim 6.0 \mathrm{GPa}$, respectively (Fig. 1a). Pressures slightly above $6 \mathrm{GPa}$ were deduced for the Cpx inclusions in diamonds from Arkhangelsk kimberlites (Sobolev et al., 1997a), while the clinopyroxenes from Yakutian diamonds (Sobolev et al., 2004; Sobolev et al., 1997b) corresponds to pressures lower than $6 \mathrm{GPa}$ (Fig. 1b). The lowest pressures (less than $5 \mathrm{GPa}$ ) were recorded for the Cpx in diamonds from Mir and Sputnik pipes (Sobolev et al., 1997b). The clinopyroxenes in diamonds of African and North American kimberlites typically record pressures between 5 and $6 \mathrm{GPa}$. Some inclusions from diamonds from the Kankan and Snap Lake localities (Stachel et al., 2000; Pokhilenko et al., 2004) suggest pressures of about 6.5 GPa (Fig 1c, d).
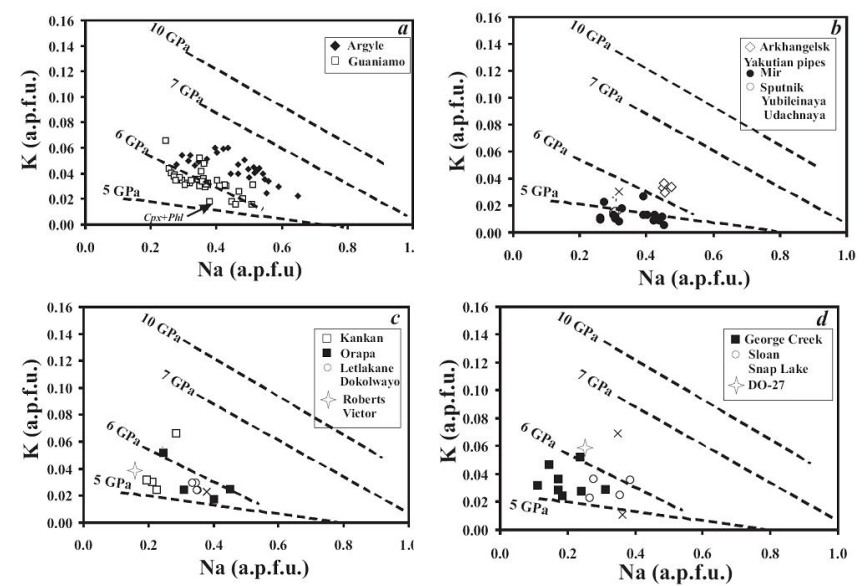

Fig. 1 Compositions of the Cpx inclusions in diamonds (symbols) in comparison to the experimentally constructed isobars (dashed lines). The experimental data are from Safonov et al. (2004) and Harlow (1997).

Empirical calibration of equilibrium $\mathrm{KAlSi}_{2} \mathrm{O}_{6}(\mathrm{Cpx})$ $=\mathrm{KAISi}_{2} \mathrm{O}_{6}$ (melt)

Using the available experimental data on composition of the KCpx equilibrated with melts of diverse compositions, we have derived (Safonov et al., 2005b) an empirical thermodynamic equation for the equilibrium $\mathrm{KAlSi}_{2} \mathrm{O}_{6}$ (in $\left.\mathrm{Cpx}\right)=\mathrm{KAlSi}_{2} \mathrm{O}_{6}$ (in melt), which allows an estimation of the pressure from the temperature and the compositions of the $\mathrm{Cpx}$ and melt:

$P(G P a)=\frac{-\left[\Delta H+R T \ln \left(\frac{X_{K}^{L}}{X_{K}^{M 2} X_{A l}^{M 1}\left(X_{S i}^{T}\right)^{2}}\right)-W_{K C a} X_{C a}^{M 2}\left(1-X_{K}^{M 2}\right)\right]}{10000 \cdot\left[\Delta V+W_{A I S i}\left(X_{A l}^{L}\right)^{2} X_{S i}^{L}\right]}$

In this equation $\Delta H=-48748( \pm 5018) \mathrm{J} / \mathrm{mol}, \Delta V=$ $0.326( \pm 0.043) \mathrm{J} / \mathrm{mol} / \mathrm{bar}, W_{\mathrm{KCa}}=53806( \pm 4882) \mathrm{J} / \mathrm{mol}$, 
$W_{\mathrm{AlSi}}=19.42( \pm 1.76) \mathrm{J} / \mathrm{mol} / \mathrm{bar}, X_{\mathrm{K}}^{\mathrm{M} 2}, X_{\mathrm{Ca}}^{\mathrm{M} 2}, X_{\mathrm{Al}}^{\mathrm{M} 1}$ and $X_{\mathrm{Si}}{ }^{\mathrm{T}}$ are the mole fractions of $\mathrm{K}$ and $\mathrm{Ca}$ in the $\mathrm{M} 2$ site, $\mathrm{Al}$ in the $\mathrm{M} 1$ and $\mathrm{Si}$ in the $\mathrm{T}$ site of $\mathrm{Cpx}$, respectively, $X_{\mathrm{K}}^{\mathrm{L}}, X_{\mathrm{Al}}^{\mathrm{L}}$ and $X_{\mathrm{Si}}{ }^{\mathrm{L}}$ are the fractions of $\mathrm{K}, \mathrm{Al}$, and $\mathrm{Si}$ in the melt. The mole fractions in the melt were calculated with the equation $X_{i}^{\mathrm{L}}=i /(\mathrm{Si}+T i$ $+A l+C r+F e+M n+M g+C a+N a+K)$, where the symbols denote numbers of moles of the elements in the melt formula unit normalized to 12 negative charges. The parameters of Equation 1 were optimized using the results of 43 experiments (Safonov et al., 2005b). The equation allows to estimate the pressure with an accuracy of $\pm 0.9 \mathrm{GPa}$ and is applicable within the intervals of 1-11 GPa and $1000-1900^{\circ} \mathrm{C}$. The equation was tested using the compositions of co-existing inclusions of $\mathrm{Cpx}$ and aluminosilicate melt in diamonds from the Mir pipe (Bulanova et al., 1993) and the co-existing Cpx and quenched melts preserved in a partially molten eclogite xenolith from the Udachnaya pipe, Yakutia (Shatsky et al., 2005). The calculated pressures are close to the diamond-graphite boundary (Fig. 2).

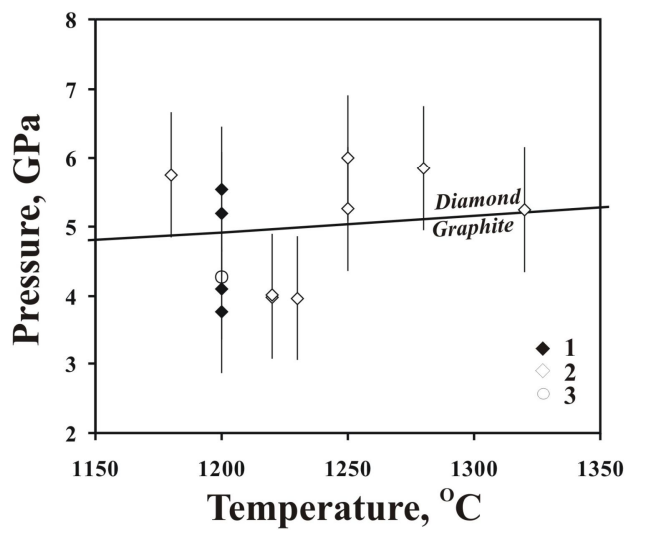

Fig. 2. The results of the pressure calculation for the KCpx + melt assemblages in diamonds (1,2 - Mir, Bulanova et al. 1993) and in partially molten eclogite nodule (3 Udachnaya, Shatsky et al., 2005).

\section{Thermodynamic assessment of mineral equilibria}

The limited range of experimentally accessible compositions of the KCpx does not allow an accurate estimation of the standard properties of $\mathrm{K}$-jadeite $\left(\mathrm{KAlSi}_{2} \mathrm{O}_{6}, \mathrm{KJd}\right)$ and the thermodynamic mixing parameters of the $\mathrm{KCpx}$ solid solution. Computer simulations offer a viable alternative. Here we have used a set of empirical interatomic potentials to calculate the static lattice energies of 800 structures within a $2 \times 2 \times 4$ supercell of $C 2 / c$ pyroxene with compositions between $\mathrm{CaMgSi}_{2} \mathrm{O}_{6}$ and $\mathrm{KAlSi}_{2} \mathrm{O}_{6}$ and different states of order of the $\mathrm{K} / \mathrm{Ca}$ and $\mathrm{Mg} / \mathrm{Al}$ cations. The excess enthalpies of these structures were cluster expanded in the basis set of 37 pairinteractions. The derived approximation for the excess enthalpy was used within a Monte Carlo algorithm to simulate temperature dependent mixing properties in the range of 273-2023 K and to calculate a temperature-composition phase diagram for the Di-KJd solid solution. First principles calculations based on density functional theory were used to estimate the standard enthalpy of formation $\left(\Delta_{f} H^{0}\right.$ $=-2932.7 \mathrm{~kJ} / \mathrm{mol})$, volume $\left(V^{0}=6.479 \mathrm{~J} / \mathrm{mol} / \mathrm{bar}\right)$, and bulk modulus $\left(K=110.69 \mathrm{GPa}^{-1}\right)$ of $\mathrm{K}$-jadeite. The standard entropy of $\mathrm{KJd}\left(S^{0}=141.24 \mathrm{~J} / \mathrm{mol} / \mathrm{K}\right)$ was calculated on the basis of the force field model.

The simulations suggested that the mixing is complete above $1000 \mathrm{~K}$, while at lower temperatures several intermediate ordered compounds become stable. The compound at $X_{\mathrm{KJd}}=0.5$ with the space group $P 2 / b$ is analogous to Na-omphacite, but has an inverted cation distribution: $\mathrm{K}$ and $\mathrm{Ca}$ in $\mathrm{K}$-omphacite occupy positions which would be $\mathrm{Ca}$-rich and $\mathrm{Na}$-rich, respectively, in Naomphacite. The instability of "normal" omphacite in the $\mathrm{K}$-system is consistent with the experimentally observed anti-correlation between $\mathrm{K}$ and $\mathrm{Na}$ contents in natural omphacites (Fig. 1). Using the estimated standard properties of the KJd end-member, and the simulated thermodynamic mixing properties of the solid solution between diopside and $\mathrm{K}$-jadeite, we calculated the isopleths of $\mathrm{KJd}$ in the $\mathrm{KCpx}$ in various mineral assemblages. The isopleths in the assemblage with sanidine (San) and coesite (Coe) show an increase in the KJd content with pressure, while the opposite tendency is predicted in the assemblage with hollandite (Hol) and stishovite (Sti) (Fig. 3a). In the assemblage with melt and coesite, the KJd-isopleths have positive slopes (Fig. 3b). A decrease in the $\mathrm{KAlSi}_{3} \mathrm{O}_{8}$ activity in the melt displaces the isopleths to higher pressures.
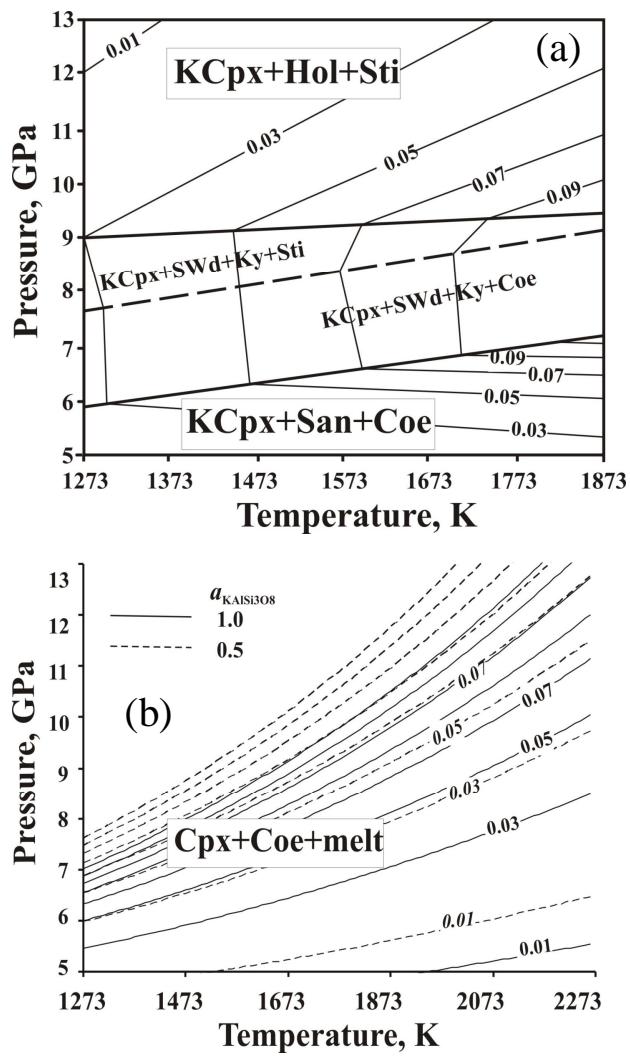

Fig. 3. P-T isopleths of $X_{\mathrm{KJd}}$ in the Cpx in the system diopside$\mathrm{KAlSi}_{3} \mathrm{O}_{8}-\mathrm{SiO}_{2}$ : (a) The assemblages with $\mathrm{San}+\mathrm{Coe}, \mathrm{Si}-$ wadeite $(\mathrm{SWd})+$ kyanite $(\mathrm{Ky})+\mathrm{Coe}(\mathrm{Sti})$ and Hol + Coe (Sti); (b) The assemblage with Coe + melt at different activities of $\mathrm{KAlSi}_{3} \mathrm{O}_{8}$ in the melt. 
The predicted range of the KJd concentrations in Cpx in these assemblages (Fig. 3a,b) is in good agreement with the available experimental data. The diagram of Figure $3 b$, when applied to the Cpx inclusions in diamonds from the Mir pipe (Bulanova et al., 1993), at the assumed temperature of 1100$1200^{\circ} \mathrm{C}$ gives pressures slightly above $5 \mathrm{GPa}$. This result is consistent with our estimates based on the empirical calibrations described above. We plan to further improve the thermodynamic description of the Cpx solid solution by including hedenbergite and jadeite components in the simulation studies.

Acknowledgments. The study is supported by the RFBR (07-05-00499), the RF President's Grant (MD-130.2008.5), Russian Science Support Foundation, the RAS Project P-9, and the Deutsche Forschungsgemeinschaft (Wi 1232/27-1).

\section{References}

Bindi L., Safonov O.G., Litvin Y.A., Perchuk L.L., Menchetti S. (2002) Ultrahigh potassium content in the clinopyroxene structure: an X-ray single-crystal study. Eur. J. Mineral., V. 14, P. 929-934.

Bindi L., Safonov O.G., Yapaskurt V.O., Perchuk L.L., Menchetti S. (2003) Ultrapotassic clinopyroxene from the Kumdy-Kol microdiamond mine, Kokchetav Complex, Kazakhstan: Occurrence, composition and crystal-chemical characterization. Am. Mineral., V. 88, P. 464-468.

Bindi L., Downs R.T., Harlow G.E., Safonov O.G. et al. (2006) Compressibility of synthetic potassium-rich clinopyroxene: In situ high-pressure single-crystal x-ray study. Am. Mineral., V. 91, P. 802-808.

Bulanova G.P., Barashkov Yu.P., Talnikova S.B., Smelova G.B. (1993) Natural diamond - genetic aspects. Novosibirsk, 168 p. (in Russian).

Chudinovskikh L.T., Zharikov V.A., Ishbulatov R.A., Matveev Y.A. (2001) On the mechanism of incorporation of ultra-high amounts of potassium into clinopyroxene at high pressure. Doklady Earth Sci., V. 380, P. 1-4.

Ghorbani M.R., Middlemost E.A.K. (2000) Geochemistry of pyroxene inclusions from the Warrumbungle Volcano, New South Wales, Australia. Am. Mineral., V. 85, P. 1349-1367.

Harlow G.E. (1996) Structure refinement of natural K-rich diopside: The effect of $\mathrm{K}$ on the average structure. Am. Mineral., V. 81, P. 632-638.

Harlow G.E. (1997) $\mathrm{K}$ in clinopyroxene at high pressure and temperature: an experimental study. Am. Mineral., V. 82, P. 259-269.

Harlow G.E. (1999) Interpretation of KCpx and CaEs in clinopyroxene from diamond inclusions and mantle samples. Proc Seventh Intern Kimberlite Conf. Vol. I, Cape Town, South Africa.

Harlow G.E, Veblen D.R. (1991) Potassium in clinopyroxene inclusions from diamonds. Science, V. 251, P. 652-655.

Jaques A.L., O’Neill H.St.C., Smith C.B. (1990) Diamondiferous peridotite xenoliths form the Argyle (AK1) lamproite pipe, Western Australia. Contrib. Mineral. Petrol., V. 104, P. 255-276.

Kaminsky F.V., Zakharchenko O.D., Griffin W.L. et al. (2000) Diamond from the Guaniamo area, Venezuela. Canad. Mineral., V. 38, P. 1347-1370.

Perchuk L.L., Safonov O.G., Yapaskurt V.O., Barton J.M., Jr. (2002) Crystal-melt equilibria involving potassium-bearing clinopyroxene as indicators of mantle-derived ultrahigh-potassic liquids: an analytical review. Lithos, V. 60, P. 89-111

Pokhilenko N.P., Sobolev N.V., Reutsky V.N. et al. (2004) Crystalline inclusions and C-isotope ratios in diamonds from the Snap Lake/King Lake kimberlite dyke system: evidence of ultradeep and enriched lithospheric mantle. Lithos. V. 77, P. 57-67

Ricard R.S., Harris J.W., Gurney J.J., Cardoso P. (1989) Mineral inclusions in diamonds from the Koffiefontein Mine. Geol. Soc. Australia Spec. Pub., V. 14, P. 10541062.

Safonov O.G., Litvin Y.A., Perchuk L.L., Bindi L., Menchetti L. (2003) Phase relations of potassium-bearing clinopyroxene in the system $\mathrm{CaMgSi}_{2} \mathrm{O}_{6}-\mathrm{KAlSi}_{2} \mathrm{O}_{6}$ at 7 GPa. Contrib. Mineral. Petrol., V. 146, P. 120-133.

Safonov O.G., Litvin Y.A., Perchuk L.L. (2004) Synthesis of omphacites and isomorphic features of clinopyroxenes in the system $\mathrm{CaMgSi}_{2} \mathrm{O}_{6}-\mathrm{NaAlSi}_{2} \mathrm{O}_{6}-\mathrm{KAlSi}_{2} \mathrm{O}_{6}$. Petrology, V. 12, P. 84-97.

Safonov O.G., Perchuk L.L., Litvin Yu.A., Bindi L. (2005a) Phase relations in the $\mathrm{CaMgSi}_{2} \mathrm{O}_{6}-\mathrm{KAlSi}_{3} \mathrm{O}_{8}$ join at 6 and $3.5 \mathrm{GPa}$ as a model for formation of some potassium-bearing deep-seated mineral assemblages. Contrib. Mineral. Petrol., V. 149, P. 316-337.

Safonov O.G., Perchuk L.L., Litvin Yu.A. (2005b) Equilibrium K-bearing clinopyroxene-melt as a model for barometry of mantle-derived mineral assemblages. Russ. Geol. Geophys., V. 46, P. 1300-1316.

Shatsky V.S., Zedgenizov D.A., Ragozin A.L. et al. (2005) Evidence for metasomatic formation of diamond in eclogite xenolith from the Udachnaya kimberlite pipe (Yakutia). Doklady Earth Sci., V. 402, P. 587-590.

Sobolev N.V., Shatsky V.S. (1990) Diamond inclusions in garnets from metamorphic rocks: a new environment for diamond formation. Nature, V. 343, P. 742-746.

Sobolev N.V., Logvinova A.M., Zedgenizov D.A. et al. (2004) Mineral inclusions in microdiamonds and macrodiamonds from kimberlites of Yakutia: a comparative study. Lithos, V. 77, P. 225-242.

Sobolev N.V., Efimova E.S., Reimers L.F. et al. (1997a) Mineral inclusions in diamonds of the Arkhangelsk kimberlite province. Russ. Geol. Geophys., V. 38, P. 358-370.

Sobolev N.V., Kaminsky F.V., Griffin W.L. et al. (1997b) Mineral inclusions in diamonds from the Sputnik kimberlite pipe, Yakutia. Lithos, V. 39, P. 135-157.

Sobolev N.V., Yefimova E.S., Channer D.M.De.R et al. (1998) Unusual upper mantle beneath Guaniamo, Guyana Shield, Venezuela: Evidence from diamond inclusions. Geology, V. 26, P. 971-974.

Stachel T., Brey G.P., Harris J.W. (2000) Kankan diamonds (Guinea) I: from the lithosphere down to the transition zone. Contrib. Mineral. Petrol., V. 140, P. 1-15.

Vinograd V.L., Safonov O.G., Wilson D.J., Bindi L. et al. (2008) Thermodynamics of Thermodynamics of diopside-K-jadeite, $\quad \mathrm{CaMgSi}_{2} \mathrm{O}_{6}-\mathrm{KAlSi}_{2} \mathrm{O}_{6}, \quad$ solid solution from quantum mechanical and static lattice energy calculations. Phys. Chem. Minerals, in press. 